RAD Conference Proceedings, vol. 4, pp. 95-100, 2020

ISSN 2466-4626 (online) | DOI: 10.21175/RadProc.2020.20

www.rad-proceedings.org

\title{
LABORATORY EXAMINATION TECHNIQUE FOR ANIMAL SKIN DERIVATIVES (HAIR, WOOL, FLUFF)
}

\author{
A.A. Oleshkevich*, S.A. Komarova, A.A. Guselnikova, E.I. Yarygina
}

Moscow State Academy of Veterinary Medicine and Biotechnology - MVA named after K.I. Scriabin, Moscow, Russia

\begin{abstract}
The hair (one of skin derivatives) structure is polymorphic, therefore the study of its specific features has diagnostic value. Nowadays, the main methods for the wool species determining are either microscopy of hair in transmitted light, or light microscopy. The relevance of the work is caused by the need to study hair and its alkaline hydrolysates using the simplest, fastest and most modern biophysical methods in order to create a laboratory test system in the future. To determine the species of animal hair, the possibility of using of the following biophysical methods was studied: polarization-interference microscopy, reflected light microscopy, fluorescence microscopy, ultraviolet spectrophotometry, and redox-measurement. Hair of different color, shape, length and thickness from animals of various classes, families and species were selected as samples. The possibilities of each method, their advantages and disadvantages were studied in samples selected. It is shown that the effectiveness of luminescence microscopy and reflected light microscopy are limited, and techniques cannot be recognized as reliably informative. The method of polarization-interference microscopy is one the most promising and can serve as alternative to reflected light microscopy. The possibility of the new redox-measurement method has been revealed. The authors have developed a special device for redox measurements and tested it in laboratory practice. The probability of the presence of a different number of absorption bands in the absorption spectra (hair species from various animals) is proven by spectrophotometric method. This allows to use ultraviolet spectrophotometry for the hair species identification. According to the authors, the most informative in laboratory identification of animal hair samples will be provided using the ultraviolet spectrophotometry method combined with the redox-potential measurement in alkaline wool hydrolysates.
\end{abstract}

Keywords: Hair, identification, polarization-interference microscopy, redox potential, spectrophotometry

\section{INTRODUCTION}

In phylogenetically similar species, subspecies and breeds of domestic animals, as well as in one individual at different stages of ontogenesis, the structure of hair differs significantly $[1,2]$. Thus, the hair can be extremely "flexible" in terms of adaptation to the environment. The structure of hair, at first glance, is very simple. A three-layer rod - a keratinized cuticular cylinder of various shapes - consists of three layers: cuticle, cortex and core. The species of hair can be determined by the structural features of each of the layers. The cortex of the hair is formed by keratinized cells. A distinctive feature of the core cells is that they dry out, shrink and die off, but do not undergo keratinization [3]. As a result of keratinization of the cells of the scaly and cortical layers, the main substance of the hair is keratin. The basic protein component of hair and wool is $\alpha$-keratin. Hair fibers are stretchable and have great elasticity, which is due to the crosslinking of the spirals by disulfide bridges [3, 4]. Keratin of the outer layer is more resistant to various chemical influences than keratin of the cortex. Cortical keratin contains tyrosine. Hair also contains pigments - melanins, which differ from skin melanins in their structure.
The rupture of disulfide bonds between two adjacent $\alpha$-helical regions (for example, when heated) leads to the dissociation of a-keratin into separate polypeptide chains. The amino acid chains of $\alpha$-keratin of animal hair contain a high content of cystine residues. They are located between peptide chains and form S-S-bonds. Hydrogen bonds are also part of the chains, which gives the chain stability, tensile strength and the ability to return to its original state $[3,4]$.

Thermochemical hydrolysis of hair with disintegration into discs is widely used for species identification of animal hair [3]. Hair core discs have a different morphology depending on the animal species, which is manifested in the disc configuration, the state of its surface and internal structure. Disks of different animals differ in structure. For example, the hair discs of the Amur tiger do not have central "cells", and the discs are built of three or four "cells" of a triangular and quadrangular shape. From the above, it follows that the hair structure is polymorphic, and the study of its specific features can be diagnostically significant $[5,6]$. Currently in the expertise [3], the main methods for determining the species of wool are either microscopy of hair in transmitted light, or light microscopy of both hair and their alkaline hydrolysis with decay into discs. The task of our work at this stage was to test the

*kompsotita@gmail.com 
possibility of studying of native hair and its alkaline hydrolysates using the simplest, fastest test-system.

\section{MATERIALS AND METHODS}

To determine the species of animal hair, the possibility of using the following biophysical methods was studied: polarization-interference microscopy, reflected light microscopy, fluorescence microscopy, ultraviolet (UV) spectrophotometry, and redox-metry.

Hair, wool or fluff of different color, shape, length and thickness from animals of different classes, families and species were deliberately selected as samples. Samples were taken from the withers.

Groups of experimental samples:

1. Domestic sheep - Ovis orientalis aries, Karakul breed, Russia, 2 females and 2 males.

2. European mink - Mustela lutreola, 3 males and 3 females, Russia, Moscow region.

3. Reindeer - Rangifer tarandus, 2 males and 2 females, Russia.

4. Siberian roe deer - Capreolus pygargus, 2 females and 2 males, Mongolia.

5. Amur tiger - Pantera tigris altaica, 3 males and 3 females, Khabarovsk Territory, Russia.

6. Silver-black fox, cell breeding - Vulpes vulpes, 3 males and 3 females, Moscow region, Russia.

7. Arctic fox - Alopex lagopus, 2 males and 1 female, Russia.

8. Polar bear - Ursus maritimus, 1 male and 3 females, Russia.

9. Domestic goat - Domesticis capra, 4 females and 3 kids, Russia.

\subsection{Polarization interference microscopy}

Polarization-interference microscopy was carried out using a BIOLAR microscope with one birefringent prism: objectives $-\mathrm{x} 40, \mathrm{~A}=0.4, \mathrm{~T}=160$. In reflected light, using a MIK-1 microscope: lenses $21 \times 0.40$; $\mathrm{T}=190$. Light and luminescence microscopy as well as sample preparation for them were carried out according to the method previously developed by the authors $[6,7,8]$. The microscopy results were photographed with a digital camera-eyepiece for a SCOPETEK microscope, model DCM35.

\subsection{Thermochemical hair hydrolysis}

The simplest and most reliable method is the technique of thermochemical hydrolysis of hair with disintegration into discs. Animal hair was placed on a glass slide. A few drops of a 10-15 \% sodium hydroxide solution were applied on top of it and carefully, in compliance with safety measures, the prepared preparation was heated over an open fire (temperature is about $100-120^{\circ} \mathrm{C}$ ). Hydrolysis was monitored visually. The exposure time was, depending on the type of hair, from 5 to 20 minutes. The obtained samples were examined in a polarization-interference microscope and filmed with a digital camera-eyepiece.

\subsection{Preparation of alkaline hair hydrolysates}

A weighed portion of $10 \mathrm{mg}$ of the test hair was introduced into a tube. Then in the same test tube we added $4 \mathrm{ml}$ of $10 \%$ sodium hydroxide. The tubes were heated in a water bath at $100{ }^{\circ} \mathrm{C}$ for 3 hours. Hydrolysis was monitored visually using a polarization interference microscope.

\subsection{Spectrophotometry}

Spectrophotometry was carried out in quartz cuvettes with a volume of $3 \mathrm{ml}$ by SF-46spectrophotometer. Absorption spectra were measured at wavelengths from 240 to $400 \mathrm{~nm}$, recording results every $5 \mathrm{~nm}$. The reference sample (control) was a $10 \%$ $\mathrm{NaOH}$ solution.

\subsection{Determination of the redox potential}

The redox potential of the solutions was measured under thermostatic conditions $\left(+24^{\circ} \mathrm{C}\right)$ using a conventional laboratory $\mathrm{pH}$ meter (EV-74 type), configured as a millivoltmeter, using two electrodesmeasuring and auxiliary [7]. The EMF from the sensor was registered. The hydrolysates were incubated for 6 days in the dark before measurements. For measurements, $1 \mathrm{ml}$ of the hydrolyzate of each sample was taken.

The technique of redox-measurement developed by the authors [9] is given below.

A sample of the test material is subjected to alkaline hydrolysis until complete dissolution. The resulting hydrolysate is adjusted to $\mathrm{pH}=12.5$, after which the value of the redox potential of the resulting solution is measured. After determining, the solution is exposed to light with a given exposure. Under the action of light, a change in the redox-potential occurs (photo-redox effect). The amplitude of the photo-redox-effect for hair hydrolysates of various types is strictly specific. To measure the parameters of the photo-redox effect, a device (stand) was used that includes the following standard units: a laboratory Ph-meter/ionometer with the ability to connect to a computer, a sensor unit with appropriate electrodes, a computer with software, and a specially designed ring illuminator for light exposure to the object measurements. The totality of the possible measurement results is as follows: the value of the redox potential before exposure to light, the magnitude of the change in the redox potential during exposure to light and the value of the redox potential after the termination of exposure to light [9].

\subsection{Luminescence intensity measurement}

The luminescence intensity of samples was determined by the measurements on a standard XLo03 chemiluminometer (UGATU, Ufa, Russia). The signal was recorded with a computer connected to the chemiluminometer; the universal PowerGraph program served as the software.

\subsection{Statistical analysis}

At least 10 measurements were performed with each sample. The results were statistically processed using the "Statistics 6.0" software package. Methods of 
descriptive statistics, correlation and multivariate analysis of variance according to Fischer were used. The differences were considered significant at $\mathrm{p}<0.05$.

\section{RESULTS AND DISCUSSION}

Wool fibers are almost entirely composed of proteins of the keratin group and a large amount of sulfur (2.5\%). An increase in the sulfur content in wool increases its strength $[1,2]$. The composition of wool fibers contains 18 ...20 amino acids. The main ones are sulfur amino acids - meteonine, cystine, cysteine. To reveal the features in the values of the optical density of alkaline hydrolysates of wool from various mammalian species, to determine the differences in the positions of the absorption minima and maxima, the absorption spectra measurements were carried out in the UV region of the spectrum. That would give reason to assume that there are significant differences in the structure and composition of keratins. By virtue of the presence of sulfur-containing (cystine) and aromatic (tryptophan, tyrosine) amino acids in keratins [3, 4], a spectrophotometric study of alkaline hydrolysates of animal hair was carried out.

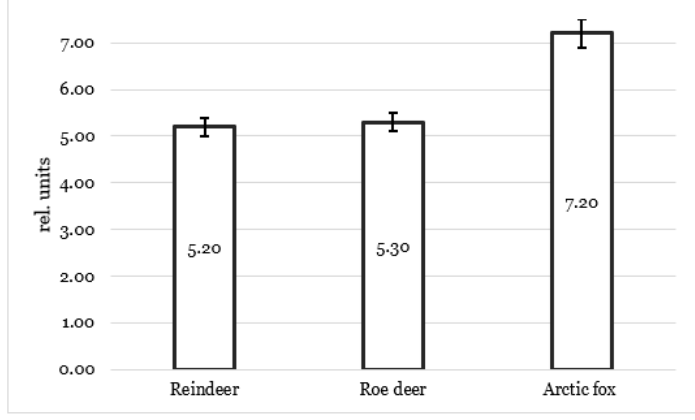

(a)

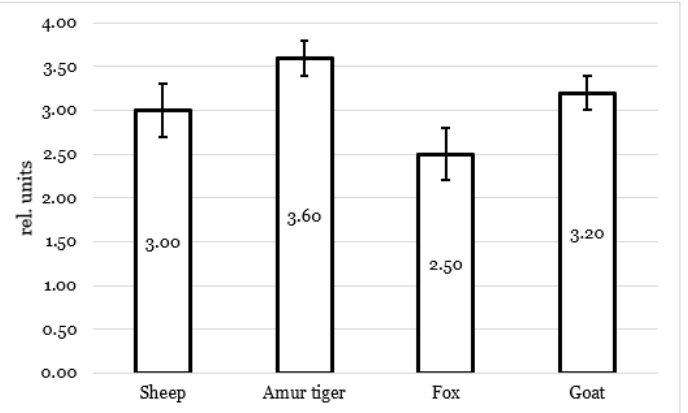

(b)

Figure 1. Luminescence intensity of hair of various animals: well luminescent (a), weak luminescent (b). X-axis: animal

fur samples; Y-axis: luminescence intensity, rel. units.

According to the results of the luminescence microscopy, all hair samples from different animals can be contingently (with a reservation) divided into three groups:

1. "Well luminescent" - the luminescence intensity exceeds 5 rel. units (Figure 1a). We included animal hair in this group, in which the cellular structure of the hair core was clearly visible using this method. These include the following samples: Reindeer hair, Roe deer hair, Arctic fox hair.

2. "Weak luminescent" - the luminescence intensity ranged from 2 to 4 rel. units (Figure $1 \mathrm{~b}$ ). The luminescence of the hair was recorded, but the structure of the core could not be distinguished in: Sheep hair, Amur tiger hair, Fox hair, Goat hair.

3. "Non-luminescent" group included hair from European mink and Polar bear.

The method of recording the luminescence of hair can be informative in some cases [10]. However, in veterinary expertise it can be confidently recommended to use for hair identifying of several animals, such as reindeer, roe deer or arctic fox.

Polarization interference microscopy showed more "encouraging" results. All samples were clearly visible; it was possible to identify the structure of the core (Figure 2).

The study of hair samples of all animal species in reflected light for the purpose of their identification gave practically no diagnostically significant results. Several images were obtained, but in most cases, the structure of the core was poorly visible.

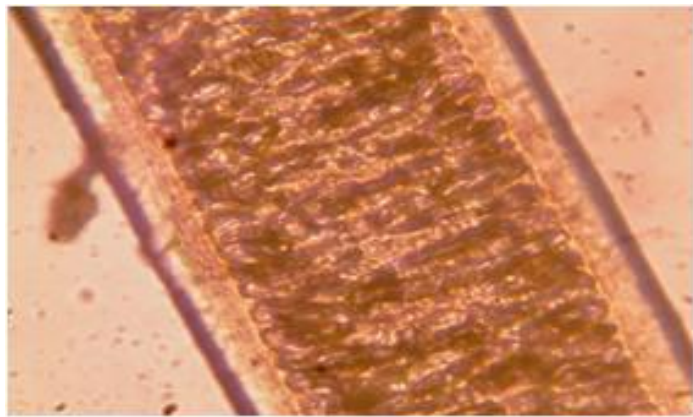

(a)

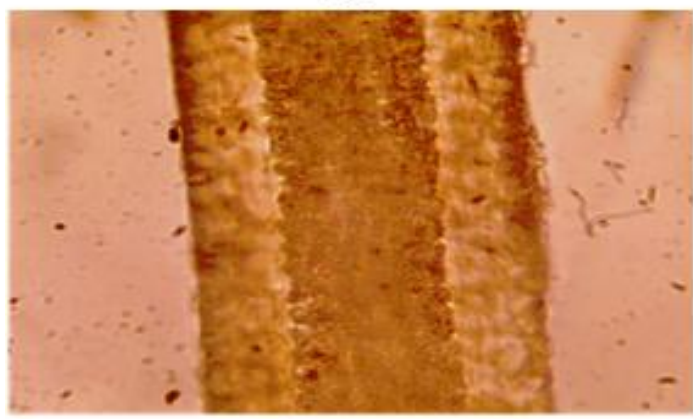

(b)

Figure 2. Micrograph of mink hair (a) and goat hair (b), polarization interference microscope (Microscope magnification x 400)

On the contrary, UV spectrophotometry, in our opinion, can be attributed to promising methods of laboratory expertise. The spectra obtained on the SF-46 spectrophotometer have characteristic differences in the absorption bands of hair of different classes, families and species of animals. 
On the Figure 3 is shown the dependence of optical density on the wavelength of hair hydrolysates from goatlings at the age of 4-6 months, the color of the wool is white. The graph shows that the peak value in the absorption band corresponds to the wavelength of $285 \pm 5 \mathrm{~nm}(\mathrm{p} \leq 0.05)$.

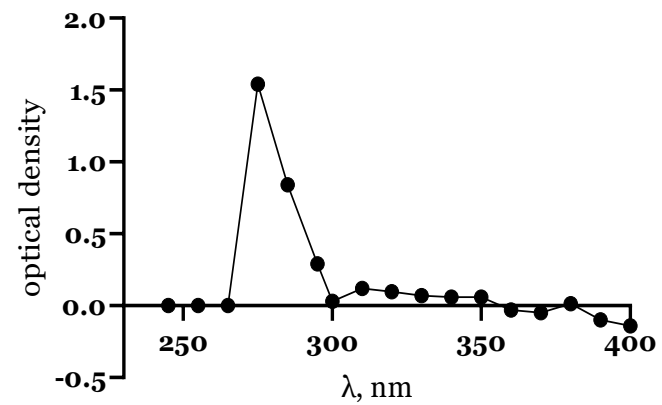

Figure 3. Dependence of optical density on the wavelength of absorbed light of hair hydrolysates from goatlings 4-6 months old

The dependence of the optical density on the wavelength of hydrolysates of goat hair (female age group, 2-4 years old, the color of the coat was visually brown) was revealed (Figure 4). Peak value in the absorption band corresponds to the wavelength of $375 \pm 5 \mathrm{~nm}(\mathrm{p} \leq 0.05)$. However, the absorption of light by solutions continued up to wavelengths of $755 \pm 5 \mathrm{~nm}(\mathrm{p} \leq 0.05)$.

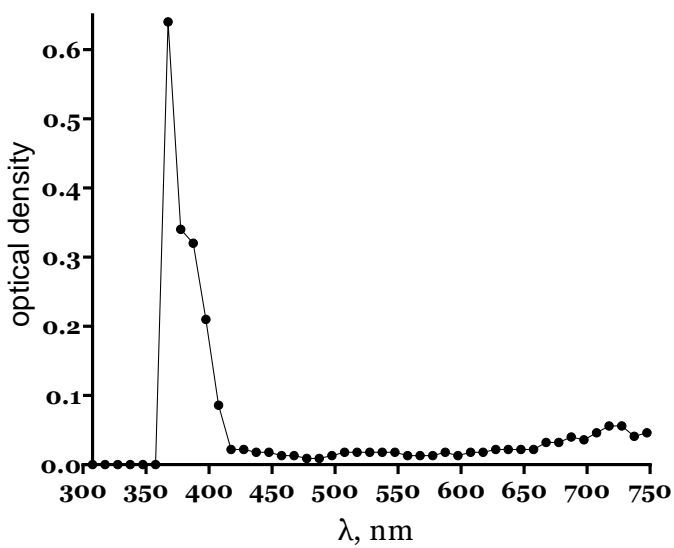

Figure 4. Dependence of the optical density on the wavelength of absorbed light by hair hydrolysates from goats; female, age group 2-4 years.

Increase of the optical density of solutions from the wool from young kids of goats is determined in the wavelength ranges of $275^{-} 350 \mathrm{~nm}$. In adult females' wool solutions, light absorption band was determined at wavelengths of $360-750 \mathrm{~nm}$, which could be associated not only with the chemical composition of keratins, but also with the chemical composition of melanins, which determine the color of the coat, as well as with the accumulation of various chemical impurities in the hair with age.
The beginning of the first absorption band of mink wool coincides with the beginning of the absorption band of bear hair, and then overlaps it and is 220-250 $\mathrm{nm}$. The second absorption band in the spectrum lies in the wavelength range of 275-295 nm. At present, work is underway to explain the presence of the identified species features in the absorption spectra. However, the presence in the spectra of a different number of absorption bands in hair from different animal permit to use the UV spectrophotometry to determine the species of hair.

Table 1. Change in redox potential, $\mathrm{mV}^{*}(-1)$.

\begin{tabular}{|c|c|c|c|c|}
\hline № & $\begin{array}{c}\text { Species of } \\
\text { wool }\end{array}$ & Mean & $\begin{array}{c}\text { Standard } \\
\text { deviation }\end{array}$ & $\begin{array}{c}\text { Fraction of } \\
\text { deviation } \\
\text { (\%) from } \\
\text { the mean }\end{array}$ \\
\hline 1 & $\begin{array}{c}\text { Domestic } \\
\text { sheep }\end{array}$ & -132.5 & 2.3 & $0.35 \%$ \\
\hline 2 & $\begin{array}{c}\text { European } \\
\text { mink }\end{array}$ & -280.0 & 1.0 & $1.13 \%$ \\
\hline 3 & Reindeer & -141.3 & 2.0 & $1.43 \%$ \\
\hline 4 & $\begin{array}{c}\text { Siberian roe } \\
\text { deer }\end{array}$ & +177.5 & 0.8 & $0.45 \%$ \\
\hline 5 & Amur tiger & +220.0 & 3.8 & $1.71 \%$ \\
\hline 6 & $\begin{array}{c}\text { Silver-black } \\
\text { fox }\end{array}$ & -195.0 & 5.7 & $2.90 \%$ \\
\hline 7 & Arctic fox & -245.0 & 3.4 & $1.39 \%$ \\
\hline 8 & Polar bear & -165.0 & 3.5 & $2.09 \%$ \\
\hline 9 & $\begin{array}{c}\text { Domestic } \\
\text { goat }\end{array}$ & -147.8 & 2.5 & $1.65 \%$ \\
\hline
\end{tabular}

Earlier, it was revealed that the change in the redox-potential of hair under the influence of light caused by the ratio of sulfhydryl (SH-) and disulfide (SS-) groups $[1,2]$. The redox potential's data obtained showed that they are different not only in species from various animals. The redox potential values changed both after irradiations of solutions with light and after incubation of the samples in the dark. In some cases, the potential shift under illumination "turned" in a more acidic medium, in the other - in more reduced form. The tested method was so informative and sensitive that it was decided to assemble and mount a trial laboratory stand [7], which is now successfully used in lecture demonstrations and laboratorypractical classes at the Department of Biophysics of the Moscow State Veterinary Academy. Nevertheless, it would be premature to position the method as a readymade test system, since it can be seen from the diagram that the values of redox potentials of hair extracts from various animal species can be similar (Table 1). All measurement data depend on the etiology of the studied material and are its digital biological characteristics.

For wool from young kids of goats and adults, the results of regression and correlation analysis between the wavelength of the light absorption band and the 
age of the animal showed the presence of close $(|r|>0.67)$ negative correlations $(p<0.001)$. It is likely that age-related morphological changes in the skin and hair of animals lead to a shift in the absorption band.

Nonetheless, there were practically no differences in the values of redox potentials in samples of wool from goats of different age groups; the values of redox potentials were within the confidence intervals ( $\mathrm{p} \leq 0.05)$. Therefore, it seems promising to carry out work to increase the sensitivity of the method for redox potentials measuring after preliminary preparation of alkaline and acidic wool hydrolysates [11,12].

In our opinion, the most informative could be combined UV-spectrophotometry and redox measurement complex method. An extended series of biophysical experiments has shown that it is impossible to obtain the same values of both redox potentials and absorption bands for any type of hair.

In our opinion, the most informative could be combined UV-spectrophotometry and redox measurement complex method. An extended series of biophysical experiments and multivariate analysis of variance according to Fischer have shown that it is impossible to obtain the same values of both redox potentials and absorption bands for any type of hair.

\section{CONCLUSION}

Thus, after preliminary approbation of a number of biophysical methods, such as polarization interference microscopy, reflected light microscopy, fluorescence microscopy, UV spectrophotometry and redox measurement, there was shown that the effectiveness of the use of fluorescence microscopy and reflected light microscopy to determine the species of animal hair is limited (due to insufficient informativeness).

On hair samples of various animal species, the features of each method, its advantages and disadvantages were studied. The method of polarization-interference microscopy is recognized to be the most promising and alternative to the reflected light microscopy method.

The possibility of our new redox-measurement technique for the identification of hair from animals of various classes, families and species has been revealed.

The presence of a different number of absorption bands in the absorption spectra of wool extracts from different animal species is shown. This indicates that the UV-spectrophotometry to be an informative method for the laboratory examination of hair and wool.

In laboratory identification of animal hair, the most reliable data can be obtained using the UV spectrophotometry method combined with redoxmetry. The fundamental researches including biochemical analysis of skin derivatives from different species of animals, as well as molecular biophysical analysis are under way. However, it is precisely the applied aspect of biophysical research that is in demand by the experts of the academy, i. m. the creation of a laboratory installation and equipment (available, inexpensive, easy-to-use complex technique), allowing relatively quick determination of the presence/absence of falsification in fur production. In connection with the above, authors have created the device and developed the foundations of the examination method.

Acknowledgements: The authors express their sincere and deep gratitude to their Teacher, Viktor E. Novikov - who died suddenly in August of this year - for a long and fruitful joint work [9, 13]. This scientific study of ours was the last [9].

\section{REFERENCES}

1. А. И. Сапожникова, И. М. Гордиенко, В. И. Хачиянц, О. В. Овсянкина, "Выделение и характеристика фибриллярных белков из отходов сырья животного происхождения," Вопросы улучшения качества и рационального использования сырья животного происхождения и продуктов животноводства: Межвед: сб. науч. тр, Москва, Россия, 1990, c. 100-106. (A. I. Sapozhnikova, I. M. Gordienko, V. I. Khachiyants, O. V. Ovsyankina, "Isolation and characterization of fibrillar proteins from wastes of raw materials of animal origin," Issues of improving the quality and rational use of raw materials of animal origin and animal products: Interved: collection of scientific articles, Moscow, Russia, 1990, pp. 100-106.)

2. В.И. Хачиянц, А. И. Сапожникова, "Изменение химического состава кератин-содержащих отходов в процессе их растворения," Вопросы улучшения качества и рационального использования сырья животного происхождения и продуктов животноводства: Межвед: сб. науч. тр. Москва, Россия, 1990, с. 91-95. (V. I. Khachiyants, A. I. Sapozhnikova, "Change in the chemical composition of keratin-containing wastes in the process of their dissolution," Issues of improving the quality and rational use of raw materials of animal origin and animal products: Interved: collection of scientific articles, Moscow, Russia, 1990, pp. 91-95.)

3. О.Ф. Чернова, “Архитектоника и диагностическое значение коры и сердцевины волос," Известия РАH, № 1, c. 73-83, 2004. (O. F. Chernov, "Architectonics and diagnostic significance of the cortex and core of the hair," Izvestiya RAN, no. 1, pp. 73-83, 2004.)

Retrieved from:

https://www.elibrary.ru/item.asp?id=17277643 Retrieved on: September 30, 2020

4. Е. В. Слепнева, "Модификация шерстяного сырья как метод улучшения физико-механических характеристик волокон," Вестник технологического университета, том 18, № 9, с. 188-190, 2015. (E. V. Slepneva "Modification of wool raw materials as a method of improving physical and mechanical fibers," Bulletin of Technological University, vol. 18, № 9, pp. 188-190, 2015.)

Retrieved from:

https://www.elibrary.ru/item.asp?id $=23719145$ Retrieved on: September 30, 2020

5. Н. И. Белик, “Тонина шерсти и её связь с другими хозяйственно полезными и морфологическими признаками овец," автореферат, Ставропольский государственный аграрный университет, Ставрополь, Россия, 2013. (N. I. Belik, "Wool fineness and its relationship with other economically useful and 
morphological characteristics of sheep,” Theses, Stavropol State Agrarian University, Stavropol, Russia, 2013.) Retrieved from:

https://www.dissercat.com/content/toninshersti-i-eesvyaz-s-drugimi-khozyaistvenno-poleznymi-imorfologicheskimi-priznakami-

Retrieved on: September 30, 2020

6. С. А. Комарова, А. А. Олешкевич, "Исследование щелочных гидролизатов волос животных с целью выявления половозрастных различий и видовой принадлежности," Сборник научных трудов VI Съезда биобизиков России, том 2, Краснодар, Россия, 2019, c. 206. (S. A. Komarova, A. A. Oleshkevich, "Study of alkaline hydrolysates of animals using different sex, age and species," Collection of scientific papers of the VI Congress of Biophysicists of Russia, vol. 2, Krasnodar, Russia, 2019, p. 206)

Retrieved from:

http://conf-2019.biophys.ru/work/BioPhys-2019 V2.pdf Retrieved on: September 30, 2020

7. В.Э. Новиков, С. А. Комарова, «Устройство для определения параметров фоторедокс-эффекта в щелочных растворах кератинов,» Патент РФ № 171788, Россия 16 июня 2017. (V. E. Novikov, S. A. Komarova, "Device for determining of the parameters of the photoredox effect in alkaline solutions of keratins," RF Patent 171788, Russia, Jun. 16, 2017.) Retrieved from: https://www.elibrary.ru/item.asp?id=38296394 Retrieved on: October 03, 2020

8. А. А. Олешкевич, С. А. Комарова, В. Н. Шевкопляс, "Анализ физиологических особенностей производных кожи биофизическими методами,” Актуальные вопросы ветеринарной биологии (A. A. Oleshkevich， S. A. Komarova， V. N. Shevkoplyas, "Analysis of the physiological functions of skin derivatives by biophysical methods," Actual Issues of Veterinary Biology, pp. 3-7, 2019.) https://doi.org/10.24411/2074-5036-2019-10030

9. S. A. Komarova, A. A. Oleshkevich, V. E. Novikov, "Device for redox-potential measurement," in Book of Abstr. $8^{\text {th }}$ Int. Conf. Radiation in Various Fields of Research (RAD 2020), Herceg Novi, Montenegro, Virtual Conference, 2020, p. 27.

Retrieved from:

https://www.rad-conference.org/Book of AbstractsRAD 2020.pdf

Retrieved on: September 23, 2020

10. A. Ehlers, I. Riemann, M. Stark, K. Kőnig, "Multiphoton fluorescence lifetime imaging of human hair," Microscopy Research and Technique, vol.70, pp. 154-161, 2007. https://doi.org/10.1002/jemt.20395

11. Zs. Éhen, Cs. Novák, J. Sztatisz, O. Bene, "Therma characterization of hear using tg-ms combined thermoanalytical," Journal of Thermal Analysis and Calorimetry, vol. 78, pp. 427-440, 2004. https://doi.org/10.1023/b:jtan.0000046108.29225.b2

12. V. F. Monteiro, A. P. Maciel, E. Longo, "Thermal analysis of Caucasian human hears," Journal of Thermal Analysis and Calorimetry, vol. 79, pp. 289-293, 2005 https://doi.org/10.1007/s10973-005-0051-9

13. S. A. Komarova, A. A. Oleshkevich, V. E. Novikov, "Pelage alkaline hydrolysates' redox change via light flash," in Book of Abstr. 5th Int. Conf. Radiation and Applications in Various Fields of Research (RAD 2017), Budva, Montenegro, 2017, p. 70

Retrieved from:

https://www.rad-conference.org/Book of AbstractsRAD 2017.pdf Retrieved on: September 23, 2020 